IRSH 67 (2022), pp. 65-95 doi:10.1017/S0020859021000432

(C) The Author(s), 202 I. Published by Cambridge University Press on behalf of Internationaal Instituut voor Sociale Geschiedenis

\title{
From Slaves and Servants to Citizens? Regulating Dependency, Race, and Gender in Revolutionary France and the French West Indies*
}

\author{
R A FFAELLA S A R TI (1) \\ DISCUI, Università degli Studi di Urbino Carlo Bo \\ Palazzo Petrangolini, Piazza Rinascimento 7 \\ 61029 Urbino (PU), Italy \\ E-mail: raffaella.sarti@uniurb.it
}

ABSTRACT: A crucial aspect of the regulation of domestic service is the regulation of people's status. Because of its emphasis on freedom and equality, the French Revolution is particularly interesting. "Men are born and remain free and equal in rights. Social distinctions may be based only on considerations of the common good." These principles of the Declaration of the Rights of Man and Citizen (26 August 1789) did not seem to leave room for slavery and master/servant hierarchies. Yet, their impact on slaves and servants was ambivalent, as I shall show by focusing on France and its Caribbean colonies. Dependency, race, and gender are crucial in my analysis. After sketching the features of servants, serfs, slaves, and indentured servants at the end of the Ancien Régime, I will analyse how the Revolution affected them, focusing on serfs and servants in metropolitan France, on black colonial slaves, and on female slaves and servants. While I investigate the "French imperial nation-State", I will also provide some comparison with the American case. The Revolution led to a feminization of dependence both in metropolitan France and in the French Caribbean, making dependence more gendered. It abolished serfdom and slavery, and enfranchised male domestiques. Thus, on the one hand, it was really revolutionary; on the other, colonial slavery was first replaced by bonded labour and then reintroduced. Male domestiques were enfranchised briefly and only on paper; they would be enfranchised when slavery in the French colonies was abolished (I 848). Women were excluded: mistresses and maids had to wait until 1944 to become full citizens. This makes it impossible to establish clear-cut distinctions between pre-revolutionary and postrevolutionary times, and in part challenges the difference between metropole and colonies.

* If not otherwise indicated, translations are by the author. I am grateful to Aad Blok, Patrizia Delpiano, Victoria Haskins, Samita Sen, and the anonymous reviewers for their suggestions. English revisions are by Clelia Boscolo. 


\section{INTRODUCTION}

"Men are born and remain free and equal in rights. Social distinctions may be based only on considerations of the common good." "The aim of every political association is the preservation of the natural and imprescriptible rights of Man. These rights are Liberty, Property, Safety, and Resistance to Oppression." The French Declaration of the Rights of Man and Citizen (26 August I789) ${ }^{\mathrm{I}}$ did not seem to allow master/servant hierarchies based on personal dependency. Yet, its impact was ambivalent, as I shall show in this article, which aims to expand historical knowledge on free and unfree domestic service regulation in France and the French West Indies. ${ }^{2}$ While an important aspect of such regulation is the regulation of people's status, special attention will be paid to slavery and the servants' exclusion from citizenship. Dependency, race, and gender are crucial in my analysis. Servants are contextualized in a wider range of different but partially overlapping types of dependent people (slaves, serfs, indentured servants). As race was decisive in justifying slavery and excluding some people from citizenship, information is also provided on unfree and free black and coloured people. Given the association of women with dependency and their long-lasting exclusion from the franchise, commonalities and differences of male and female servants and slaves with women as a whole will be considered in a gendered perspective. By focusing on people excluded from citizenship for a longer/shorter period, the article also contributes to citizenship history.

In the first section, I will sketch the status of different dependent people under the Ancien Régime. I will then analyse how the Revolution affected it with an intersectional analysis of the changing relationships of dependence, race, and gender, focusing on serfs and servants in metropolitan France (second section), on black colonial slaves (third section), and on female slaves and servants (fourth section). The Revolution led to a feminization of dependence in metropolitan France as well as in the French Caribbean, making dependence more gendered among both white and black/coloured people.

I will report the events affecting servants, following wide-ranging research, especially on parliamentary debates, whereas in the case of black/coloured people and women I will mainly exploit existing literature. While such literature is huge, the originality of the article lies in bringing together issues often analysed separately, and in studying both metropolitan France and the colonies. Far from expressing a "methodological nationalism" that naturalizes

I. Available at: https://www.conseil-constitutionnel.fr/sites/default/files/as/root/bank_mm/anglais/ cst2.pdf; last accessed 28 May 202 I.

2. Saint-Domingue, Martinique, and Guadalupe were the main French West Indies colonies. Lucien-René Abénon and John A. Dickinson, Les Français en Amérique. Histoire d'une colonisation (Lyon, 1993). 
the nation state, ${ }^{3}$ this choice allows me to overcome Eurocentric perspectives, investigating the "French imperial nation-State" and the French Revolution as an Atlantic revolution. ${ }^{4}$ However, I will also provide some comparison with the American case (fifth section). The article moves towards a global approach to the history of domestic service and, to a lesser degree, slavery, ${ }^{5}$ contributing to challenge clear-cut oppositions between free and unfree labour, both in general and as features of Western and non-Western societies, respectively. ${ }^{6}$

The French Revolution created a transcontinental political arena where tensions between principles and practices were particularly rife. Some phases/ measures had a real "revolutionary character": the Revolution abolished serfdom and slavery, and enfranchised male domestiques. It provided powerful

3. Marcel van der Linden, Workers of the World: Essays toward a Global Labor History (Leiden, 2008), p. 7.

4. Laurent Dubois, "Histoires d'esclavage en France et aux États-Unis", Esprit, 332:2 (2007), pp. 7I-80; Gary Wilder, The French Imperial Nation-State: Negritude and Colonial Humanism between the Two Wars (Chicago, IL, 2005).

5. José C. Moya, "Domestic Service in a Global Perspective: Gender, Migration, and Ethnic Niches", Journal of Ethnic and Migration Studies, 33:4 (2007), pp. 559-579; Raffaella Sarti, "The Globalisation of Domestic Service: An Historical Perspective", in Helma Lutz (ed.), Migration and Domestic Work: A European Perspective on a Global Theme (Aldershot, 2008), pp. 77-98; Dirk Hoerder, Elise van Nederveen Meerkerk, and Silke Neunsinger (eds), Towards a Global History of Domestic and Caregiving Workers (Leiden, 2015); Raffaella Sarti, "Can Historians Speak? A Few Thoughts and Proposals on a Possible Global History of Domestic Service/Work", in Nitin Sinha, Nitin Varma, and Pankaj Jha (eds), Servants' Pasts: Sixteenth to Eighteenth Century. South Asia, vol. I (New Delhi, 2019), pp. 345-370; Patrick Manning (ed.), Slave Trades, I 500-I 800: Globalization of Forced Labour (Aldershot, 1996); idem, "Legacies of Slavery: Comparisons of Labour and Culture", in Maria Suzette Fernandes Dias (ed.), Legacies of Slavery: Comparative Perspectives (Newcastle-upon-Tyne, 2007), pp. 16-34; Marcel van der Linden and Magaly Rodríguez García (eds), On Coerced Labor: Work and Compulsion after Chattel Slavery (Leiden, 2016); Damian Alan Pargas, "Slavery as a Global and Globalizing Phenomenon”, Journal of Global Slavery, I:I (2016), pp. I-4; Paulin Ismard, "Écrire l'histoire de l'esclavage. Entre approche globale et perspective comparatiste", Annales. Histoire, Sciences Sociales, 72 (2017), pp. 7-43.

6. Robert J. Steinfeld, The Invention of Free Labor: The Employment Relation in English and American Law and Culture, I350-I870 (Chapel Hill, NC, I99I); Tom Brass and Marcel van der Linden (eds), Free and Unfree Labour: The Debate Continues (Bern, 1997); Douglas Hay and Paul Craven, Masters, Servants, and Magistrates in Britain and the Empire, 1562-1955 (Chapel Hill, NC, 2004); Carolyn Brown and Marcel van der Linden (eds), Shifting Boundaries between Free and Unfree Labor, Special Issue of International Labor and Working-Class History, 78 (2010); Tracy Dennison, The Institutional Framework of Russian Serfdom (Cambridge, 20II); Alessandro Stanziani, Bondage: Labor and Rights in Eurasia from the Sixteenth to the Early Twentieth Centuries (New York, 20I4); Van der Linden and Rodríguez García, On Coerced Labor; Giulia Bonazza and Giulio Ongaro (eds), Libertà e coercizione. Il lavoro in una prospettiva di lungo periodo (Palermo, 20I8); Christian G. De Vito, Juliane Schiel, and Matthias van Rossum, "From Bondage to Precariousness? New Perspectives on Labor and Social History", Journal of Social History, 54:2 (2020), pp. 644-662; Juliane Schiel and Christian G. De Vito (eds), Modalities of Coercion and Shifting Labor and Power Relations, Special Issue of Journal of Global Slavery, 5:2 (2020). 
arguments to support later claims of rights. Yet, colonial slavery was first replaced by bonded labour and then reintroduced. Male domestiques were enfranchised briefly and only on paper; they would actually be enfranchised when slavery in the French colonies was abolished (I 848). Women were excluded: mistresses and maids had to wait until 1944 to become full citizens. This makes it impossible to establish clear-cut distinctions between prerevolutionary and post-revolutionary times, and in part challenges the difference between metropole and colonies, although the latter witnessed extreme violence. There were similarities between colonies and households, which, even in metropolitan France, remained sites of inequalities affecting both the private and public sphere.

\section{SERVANTS AND OTHER DEPENDANTS UNDER THE ANCIEN RÉGIME?}

"In France, where there are no slaves, all domestics are free." Domestics "can leave their master when they judge it appropriate". If they leave before the appointed time, he "has only recourse to damages and interest", the Encyclopédie explained. ${ }^{8}$ This was rather "modern": at that time, people generally conceived freedom as liberty to start rather than leave a job. ${ }^{9}$ The entry mentioned few exceptions. ${ }^{\circ}$ Yet, according to the law, there were more. In I 565 , the master's written permit to leave was introduced; unemployed servants without it could be punished as vagrants. ${ }^{\text {II }}$ According to the 1567 and

7. For comparisons: Raffaella Sarti, "Who Are Servants? Defining Domestic Service in Western Europe (16th-2 Ist Centuries)", in Suzy Pasleau and Isabelle Schopp (eds), with Raffaella Sarti, Proceedings of the Servant Project (Liège, 2005), vol. 2, pp. 3-59; Raffaella Sarti, "Freedom and Citizenship? The Legal Status of Servants and Domestic Workers in a Comparative Perspective (16th-2 Ist Centuries)", ibid., vol. 3, pp. I 27-164; idem, "Criados, Servi, Domestiques, Gesinde, Servants: For a Comparative History of Domestic Service in Europe (16th-19th Centuries)", Obradoiro de Historia Moderna, I6 (2007), pp. 9-39; idem, “'The Purgatory of Servants': (In) Subordination, Wages, Gender, and Marital Status of Servants in England and Italy in the Seventeenth and Eighteenth Centuries", Journal of Early Modern Studies, 4 (201 5), pp. 347372; idem, "The Servant's Freedom: A Few Thoughts on Slavery and Service in a Long-Term Perspective", in Bonazza and Ongaro, Libertà, pp. 69-95.

8. (A) [=Antoine-Gaspar Boucher D’Argis], "Domestiques", in Encyclopédie, on Dictionnaire raisonné des sciences, des arts et des métiers..., vol. V (Paris, 1755), p. 29, transl. The Encyclopedia of Diderot E d'Alembert (Ann Arbor, MI, 2006), "Domestics". Available at: http://hdl.handle.net/2027/spo.did2222.0000.499; last accessed 28 May 202 I. In Britain, breaching a contract was a criminal offence, see Steinfeld, The Invention, pp. 96-97.

9. Steinfeld, The Invention; Alessandro Stanziani, "Beyond Colonialism: Servants, Wage Earners and Indentured Migrants in Rural France and on Reunion Island (c.1750-1900)", Labor History, 54:I (2013), pp. 64-87; Sarti, "Freedom".

Iо. $(A)$, "Domestiques".

I I. Edict du Roy pour contenir les serviteurs et servantes en leurs devoirs (Paris, I 565); N. Guyot (ed.), Répertoire universel et raisonné de jurisprudence (Paris, I775-1783), vol. XX, pp. I I 2-I 2 I; 
I 577 police regulations, servants must work for a year if their masters so wished; those hired to perform specific tasks had to accomplish them. Servants who left without permission (except for legitimate reasons) could be sentenced to complete the work or to pay for the damage. ${ }^{\mathrm{I}}$ During the I720s, several ordinances tried to fix contract renewal on St Martin's Day (I I November), and, more effectively, to prevent farm servants from breaching their contract. ${ }^{13}$ According to a Répertoire, in large cities masters did not retain servants who asked to leave, it being easy to replace them. But in small towns and in the countryside, it was "important to maintain in all their strength the regulations which compel[led] servants to complete the time of their commitment". ${ }^{14}$ As for apprentices, eighteenth-century contracts usually established that the master/apprentice intermediary should return runaway apprentices to their masters. ${ }^{\text {Is }}$

Other entries in the Encyclopédie contradicted the alleged absence of slaves in France. "Galérien" mentioned (mainly Muslim) slaves among galley oarsmen; ${ }^{16}$ "Esclave" described the legislation that allowed colonial slaves to be brought to the metropole without freeing them. ${ }^{17}$ From the late Middle Ages, the "Freedom Principle" established that slaves setting foot on French soil became free ${ }^{18}$ Ignored in the case of enslaved oarsmen, ${ }^{19}$ it was challenged by colonial slavery. ${ }^{20}$ I 685 slavery regulations (Code Noir) did not address the

Henri Jean-Baptiste Grégoire, De la domesticité chez les peuples anciens et modernes (Paris, I 8 I 4), p. I8I; Julien P. Alletz, Dictionnaire de Police Moderne..., vol. II (Paris, I823), p. 92; Marius-Henri-Casimir Mittre, Des domestiques en France... (Paris, 1837), pp. 136-1 38, I87, I9I; Sarah C. Maza, Servants and Masters in Eighteenth-Century France: The Uses of Loyalty (Princeton, NJ, 1983), pp. 54-55; Claude Petitfrère, L'oeil du maître. Maîtres et serviteurs, de l'époque classique au romantisme (Brussels, 1986), pp. I80-182; Sarti, "Freedom", pp. I38-139. I 2. Guyot, Répertoire, vol. XX, p. I I 3, i 8 ; Jean-Pierre Gutton, Domestiques et serviteurs dans la France de l'ancien régime (Paris, $198 \mathrm{I}$ ), p. $\mathrm{I} 38$.

I3. Gutton, Domestiques, pp. I04-105; Guyot, Répertoire, vol. XX, pp. I 1 8-1 20.

I4. Guyot, Répertoire, vol. XX, quotation on p. I 18; Mittre, Des domestiques, p. I7 I.

I 5. Steven Kaplan, "L'apprentissage au XVIIIe siècle. Le cas de Paris”, Revue d'Histoire moderne et contemporaine, 40 (1993), pp. 436-479.

I6. M. Durival le jeune, "Galérien”, in Encyclopédie, vol. 7 (Paris, 1757), p. 445; André Zysberg, Les Galériens. Vies et destins de 60000 forçats sur les galères de France I680-I748 (Paris, 1991). 17. (A) [=Antoine-Gaspard Boucher d'Argis], "Esclave", in Encyclopédie, vol. 5, pp, 939-943; Sue Peabody, "There are No Slaves in France": The Political Culture of Race and Slavery in the Ancien Régime (New York, I996), p. 3.

I 8. Charles Verlinden, L'esclavage dans l'Europe médiévale, vol. I (Bruges, I955), pp. 85 I-8 54 ; Marcel Koufinkana, "Les esclaves noirs en France et la Révolution (1700-I794)", Horizons Maghrébins, I8-19 (1992), pp. I44-161; Peabody, "There are No Slaves in France”, p. 3; Sue Peabody, "An Alternative Genealogy of the Origins of French Free Soil: Medieval Toulouse", Slavery E Abolition, 32:3 (201 I), pp. 34 I-362.

19. Gillian Weiss, "Infidels at the Oar: A Mediterranean Exception to France's Free-Soil Principle”, Slavery \& Abolition, 32:3 (201 I), pp. 397-4I 2.

20. Peabody, "There are No Slaves in France", p. $5 \mathrm{I}$. 
metropole despite colonial enslaved domestics arriving with their masters. ${ }^{21}$ In I 7 I6, however, a royal edict allowed slaves to be brought to France to learn a trade or religion with the permission of the colonial authorities and subject to registration with the Admiralty. Otherwise, the slaves became free. Once trained/educated, slaves should have been returned to the colonies (but many were not). A I 738 edict limited residence to three years and established that slaves brought without the colonial governor's permission or not registered with the Admiralty would be sent back. ${ }^{22}$ The Paris Parlement did not register these edicts: within its jurisdiction, the Freedom Principle remained the rule. From the 1750s, slaves on French soil claiming freedom before Paris's Admiralty Court were freed. Nonetheless, slave numbers grew. ${ }^{23}$ France became "a public market where men [were] sold to the highest bidder". ${ }^{24}$ Race mixing was also a concern. ${ }^{25}$ An Admiralty ordinance (I762) shifting the focus to colour - established that "negroes and mulattos" should be registered, prohibiting their sale. ${ }^{26}$ In $\mathrm{I} 777$, the Déclaration pour la police des noirs (1777) forbade "blacks, mulattos, and other people of colour" from entering France to prevent blood degeneration in the metropole and revolution in the colonies (slaves returning from the metropole brought with them a spirit of liberty). ${ }^{27}$ Nonetheless, they continued to arrive. ${ }^{28}$ Despite anxieties, there were probably only 4,000-5,000 blacks in France. ${ }^{29}$

France had about 28 million inhabitants, with perhaps one million serfs. ${ }^{30}$ They were "attached to the soil" and "deprived of their personal liberty and the prerogatives of property", being "themselves among the feudal

21. Ibid., pp. I I-I3; Louis Sala-Molins, Le Code Noir ou le calvaire de Canaan (Paris, [1987] 2012).

22. Edit concernant les Esclaves des Colonies du mois d'octobre I7I6; Déclaration du Roi concernant les Nègres esclaves des Colonies [...], le Is Décembre 1738; Verlinden, L'esclavage, pp. 85 I854; Robert Allier, "L'esclavage domestique en France au dix-huitième siècle”, La Semaine Littéraire Revue hebdomadaire, 59 (I895), pp. 80-82; Gutton, Domestiques, p. 76; Peabody, "There are No Slaves in France", pp. I 5-22, 37-39; Érick Noël, "L'esclavage dans la France moderne", Dix-huitième siècle, 39: I (2007), pp. 36I-383; Pierre H. Boulle, "Élaboration et pratique de la législation sur les noirs en France au cours du XVIIIe siècle", in Fréderic Régent, Jean François Niort, and Pierre Serna (eds), Les colonies, la Révolution française, la loi (Rennes, 20I4), pp. 2 I-40.

23. Peabody, "There are No Slaves in France", p. 72.

24. Procureur du roi Poncet de la Grave, I762, in ibid., p. 73; Allier, “L’esclavage”, p. 82.

25. Koufinkana, "Les esclaves", p. I49.

26. Peabody, "There are No Slaves in France", p. 74.

27. Ibid., p. I19.

28. Ibid., pp. 106-I 20; Verlinden, L'esclavage, pp. 85 I-854; Cissie Fairchilds, Domestic Enemies Servants and Their Masters in Old Regime France (Baltimore, MD, and London, 1984), pp. I58I 59; Maza, Servants, pp. 206-207; Boulle, "Élaboration”, pp. 38-40.

29. Peabody, "There are No Slaves in France", p. xv; Boulle, "Élaboration", p. 34, note 64.

30. Thierry Bressan, "Un épisode important et méconnu du procès du régime seigneurial en France. L'édit d'août 1779 contre les survivances serviles", Histoire, économie et société, I s:4 (1996), pp. 57I-599, 573; Jacques Dupâquier and Joseph Goy, "Révolution et population”, in 
possessions". ${ }^{31}$ In the 1770 , Voltaire and the lawyer Christin campaigned for the Mont-Jura's serfs, advocating the abolition of serfdom. In I779, a royal edict, only partially enforced, abolished serfdom in the royal domains and the biens engagés, goods sold by the king with the right on the part of the king to buy them back at any time, or, according to another definition, pawned in exchange for money. ${ }^{32}$

The term engagés also had a different meaning, i.e. people who engaged themselves for three to four years to pay their passage to the colonies. They were subject to criminal sanctions for contract breaching. They could be sold, ${ }^{33}$ but following the idea that freedom implied liberty to start a job, the engagement contract was considered free. ${ }^{34}$ Yet, many engagés were vagrants and prostitutes recruited forcefully. ${ }^{35}$ About 30,000-40,000 engagés migrated to the French colonies. ${ }^{36}$ In 1774, the scheme was suppressed. It had proved unsuccessful as a way of balancing out the white population and black slaves, the import of whom was booming. ${ }^{37}$ By the late eighteenth century, there were 500,000 slaves in Saint-Domingue, ${ }^{38}$ about 700,000 in the whole French Antilles, mainly employed in sugar plantations but also in domestic service. ${ }^{39}$

Jacques Dupâquier (ed.), Histoire de la population française (3). De I789 à 1914 (Paris, 1988), pp. 63-II7.

31. Édit portant suppression du droit de main-morte et de la servitude personnelle ... (Paris, 1779).

32. Bressan, "Un épisode"; J.-M. Carou, Traité théorique et pratique des actions possessoires (Paris, I $84 \mathrm{I}^{2}$ ), p. 373; Le domaine royal et l'inaliénabilité du domaine de la couronne. Available at: https:// cours-de-droit.net/le-domaine-royal-et-son-inalienabilite-aI49788752/; last accessed 3I May $202 \mathrm{I}$.

33. Encyclopédie, vol. 5, p. 675, "Engagé ou trente-six mois (Marine)"; "Engagé (Commerce)"; Philippe Hroděj, "Les premiers colons de l'ancienne Haïti et leurs attaches en métropole, à l'aube des premiers établissements (1650-1700)", Les Cabiers de Framespa, 9 (2012). Available at: http://journals.openedition.org/framespa/ıo5o; last accessed 3 I May 202I; Stanziani, "Beyond Colonialism".

34. Stanziani, "Beyond Colonialism”, p. 71.

35. Bernard Moitt, Women and Slavery in the French Antilles, $1635-1848$ (Bloomington, IN, 200I), p. Iо.

36. Hroděj, "Les premiers", p. 3.

37. Moitt, Women, p. I I Karsten Voss and Klaus Weber, "Their Most Valuable and Most Vulnerable Asset: Slaves on the Early Sugar Plantations of Saint-Domingue (I697-I7 I5)", Journal of Global Slavery, 5:2 (2020), pp. 204-237; Léon Vignols, "Les Antilles Françaises sous l'ancien régime [...]. L'institution des engagés (1626-1774)”, Revue d'bistoire économique et sociale, I6 (1928), pp. I 2-45.

38. Marcel Dorigny, Les abolitions de l'esclavage 1793-I888 (Paris 2018), p. I07.

39. Sala-Molins, Le Code Noir, Kindle pos. 7 I 2; Frédéric Régent, "Préjugé de couleur, esclavage et citoyennetés dans les colonies françaises (1789-1848)", La Révolution française, 9 (2015), pp. I-37; Frédéric Régent, La France et ses esclaves, de la colonisation aux abolitions (1620I848) (Paris, 2007), pp. 66-68. 
There were similarities and, in some cases, even overlaps among slaves, indentured servants, serfs, servants in husbandry, apprentices, and domestic servants. The engagés' contracts were similar to those of people who "colonized" uncultivated land in France (but in the colonies the engagés could be passed onto other masters without their consent). ${ }^{\circ}$ They were considered "white slaves", although they could not be punished as severely as black slaves. Both might work as domestics, thus being simultaneously engagés and domestiques, or slaves and domestiques; ${ }^{4 \mathrm{I}}$ typically, colonial slaves brought to France were domestiques..$^{42}$ On the other hand, domestique was an "umbrella term" that might refer to very different people. Apprentices and farm servants, for instance, might be regarded as such. Consequently, people likely to be regarded as domestiques were ubiquitous. ${ }^{43}$ Furthermore a "domestic footprint" characterized many work relationships other than domestic service. ${ }^{44}$ About ten per cent of the urban population could thus be classified as domestiques: the largest category of workers, ranging from the maid-of-all-work to the house-steward. ${ }^{45}$ "Labels" classifying people were performative, aiming not only at describing, but also at shaping social reality, keeping people in what the hegemonic groups considered as "their place". This did not prevent efforts to modify the power balance using different labels or manipulating them. ${ }^{46}$

While the Encyclopédie (1755) stated that the domestiques were free, according to the Encyclopédie méthodique (I79I) many of them were in "true servitude" ${ }^{47}$ Domestic service was a "kind of slavery, seemingly voluntary but in fact real, due to the need to make a living". ${ }^{4}$ The Encyclopédie méthodique was published during the Revolution, when servitude and slavery became metaphors for the injustice that revolutionaries tried to destroy. What happened to servants, serfs, slaves of flesh and blood?

40. Hroděj, "Les premiers", p. 3.

4. Moitt, Women, p. I6; Arlette Gautier, Les sours de Solitude: Femmes et esclavage aux Antilles du XVIIe au XIXe siècle (Rennes, 2010, $1985^{\mathrm{I}}$ ), Kindle pos. 3982.

42. Peabody, "There are No Slaves in France", p. $5 \mathrm{I}$.

43. Fairchilds, Domestic Enemies, pp. 2-3; Sarti, "Who Are Servants?".

44. Corine Maitte and Nicolas Shapira (eds), L'empreinte domestique du travail, XVIeXXIe siècle, Special Issue of Mélanges de l'Ecole française de Rome, Italie et Méditerranée moderne et contemporaines. Available at: https://doi.org/I0.4000/mefrim.4826; last accessed I 3 June $202 \mathrm{I}$. Maria Luisa Pesante, Come servi. Figure del lavoro salariato dal diritto naturale all'economia politica (Milan, 2013).

45. Corine Maitte and Philippe Rygiel, “Mobilités et travail”, Historiens et Géographes, 438 (2017). Available at: https://hal-upec-upem.archives-ouvertes.fr/hal-o1646233/document; last accessed 28 May $202 \mathrm{I}$.

46. Raffaella Sarti, Servo e padrone, o della (in)dipendenza. Un percorso da Aristotele ai nostri giorni, vol. I (Bologna, 20I5), pp. 23 I-245.

47. Encyclopédie Méthodique... (Paris, I791), vol. ıо, p. 59, "Domestiques".

48. Ibid., vol. 9, p. I 5 , "Abus". 


\section{REVOLUTION! SERFS AND DOMESTIQUES}

On 5 May 1789 , the Estates General convened in Versailles. A few weeks later, the Third-Estate representatives proclaimed themselves a National Assembly: on 20 June, they swore they would give the country a constitution. In the countryside, especially after the storming of the Bastille (I4 July), the "Great Fear" of an aristocratic anti-revolutionary conspiracy led to riots and pillages. ${ }^{49}$ Serfs participated in such actions,${ }^{50}$ which persuaded the National Assembly to abolish feudal rights, including serfdom (4-5 August). ${ }^{5 \mathrm{I}}$ This led to the final disappearance of serfdom..$^{52}$

According to the abolition decree, "all citizens, without distinction of birth, [were] eligible for any ecclesiastical, civil, and military office and dignity". ${ }^{53}$ Nonetheless, the domestiques were excluded from the newborn National Guard. ${ }^{54}$ The armed defence of the nation was becoming a feature of proper citizens. Unsurprisingly, the domestics' request to participate in the National Guard intermingled with that of citizenship. "The People in a condition of domestic servitude are men and Citizens like their Masters. It is therefore neither logical nor fair to refuse them what is being granted to all masters", some servants maintained."s

On 28 August 1789, Paris's domestiques demanded their own assemblées. Despite the Déclaration des droits, issued two days earlier (26 August), their request was rejected with reference to existing laws. ${ }^{56}$ "Servants were juridically incapable of forming corporations. They were considered to be members of the family they served, under the paternal authority of its head, and they therefore had no independent juridical or social standing." 57 Some servants also suggested measures to fight servant poverty and poverty-linked crimes, to gain the trust of the public (by setting up an employment office

49. Georges Lefebvre, La Grande Peur de 1789 (Paris, I932).

50. Bressan, "Un épisode", p. 596.

5. Lettre du Roi à l'Assemblée Nationale [...] Décrets de l'Assemblée Nationale des 4, 6, 7, 8 et I I Août 1789 (Lyon, I789), p. I3, art. I.

52. Bressan, "Un épisode", p. 596.

53. Lettre du Roi, p. I6, art. I I.

54. Domestics, initially accepted, were excluded once the emergency was over. See Représentations de la livrée... (Paris, [1789]); Réglement pour la Formation [...] de l'Infanterie Nationale Parisienne (Paris, [1789]), p. 2, art. IV; Charles Comte, Histoire de la Garde Nationale de Paris (Paris, I 827), p. 43; Petitfrère, L'oeil, p. 192; Roger Dupuy, La Garde nationale: I789-I 872 (Paris, 2013).

55. Pétition des Personnes en état de Domesticité..., quoted in Maurice Genty, "Controverses autour de la Garde Nationale parisienne", Annales historiques de la Révolution française [hereafter, $A H R F$ ], 29I (1993), pp. 6I-88, 65; Sarti, Servo e padrone, pp. I 25 -I 26.

56. Sigismond Lacroix, Actes de la Commune de Paris pendant la Révolution (Paris, 1894-1942), vol. I, p. 38 ז; vol. V, p. 68.

57. William Sewell Jr., Work and Revolution in France: The Language of Labor from the Old Regime to I 848 (Cambridge, I980), p. 20; Lacroix, Actes, vol. V, p. 69, note I. 
and a fund to cover illness and unemployment). ${ }^{8}{ }^{8}$ They were ready to withdraw their earlier request to expel foreign domestiques as a means to fight unemployment. ${ }^{59}$ Nonetheless, on 29 August, about 3,000 unemployed servants rioted demanding such expulsion. ${ }^{60}$ The guards dispersed them. ${ }^{61}$

A month later, the committee that prepared the Constitution included among the requisites for political participation "not being, for the moment, in a servile condition, that is to say in personal relationships which were absolutely incompatible with the independence necessary to exercise their political rights". ${ }^{62}$ The principle was accepted as follows: "Not being in the condition of a domestic, that is to say of a waged servant" (serviteur à gage). ${ }^{63}$ Slaves and servants had been excluded from citizenship since antiquity. The reasons for excluding them changed over time, but dependency, seen as something that made free choice impossible, remained crucial. ${ }^{64}$

The exclusion hurt (at least) some domestiques. On I 2 June I790, a man from a deputation of household staff, possibly Jean Visse, was allowed to address the National Assembly. His words reveal that some stereotypes could be shared by their victims: "it is difficult to reconcile the exercise of freedom with the regime of domestic service". But they also show the servants' wounded dignity: “Are we not French?". Furthermore, they disclose a profound awareness of the socio-economic conditions that compelled the poor to serve: "need has established a dependency that a certain class of men cannot

58. Requête présentée par le corps des domestiques... (Paris, 1789).

59. Lacroix, Actes, vol. V, pp. 68-69.

60. P.J.B. Buchez et al., Histoire parlementaire de la Révolution française, vol. II (Paris, I 846),

pp. I9-20; Révolutions de Paris, No. VIII, Détails du Samedi 29 Août, p. 4.

6r. Révolutions de Paris, p. 6, no. X, p. 3 I.

62. Archives Parlementaires de 1787 à I 860 [...] Première série, 1787 à $I 799$ (Paris, I 867-...), vol. IX, p. 204 [hereafter, $A P$; numbers refer to the volume].

63. AP-IX, p. 590; Constitution, 3 September I79I, tit. III, ch. I, section. II, art. 2. Gutton, Domestiques, pp. 217-218; Maza, Servants, pp. 305-314; Fairchilds, Domestic Enemies, pp. 229-244; Petitfrère, L'oeil, pp. I89-199; Claude Petitfrère, "Liberté, égalité, domesticité", in Gérard Chianéa (ed.), Les droits de l'Homme et la conquête des libertés. Des lumières aux révolutions de 1848 (Grenoble, I988), pp. 249-256; Pierre Rosanvallon, Le sacre du citoyen. Histoire du suffrage universel en France (Paris, 1992); Anne Verjus, "Les femmes, épouses et mères de citoyens ou de la famille comme catégorie politique dans la construction de la citoyenneté (1789-I 848)" (Ph.D., École des Hautes Études en Sciences Sociales, Paris, 1997), vol. I, pp. 224-235; idem, "Vote familialiste et vote familial. Contribution à l'étude du processus d'individualisation des femmes dans la première partie du XIXe siècle", Genèses, 3 I (1998), pp. 29-47; André Tiano, Les pratiques publiques d'exclusion depuis la Révolution française (Paris, I999), p. 45; Raymonde Monnier (ed.) Citoyen et citoyenneté sous la Révolution française (Paris, 2006); Jean-Pierre Gross, "Domesticité, travail et citoyenneté en l'an II". Available at: http://revolution-francaise.net/2008/08/I 2/252-domesticite-travail-citoyennete-anii; last accessed 28 May 202I; idem, "L'émancipation des domestiques sous la Révolution française", in Marc Belissa, Yannick Bosc, and Florence Gauthier (eds), Républicanismes et droit naturel (Paris, 2009), pp. 175-187.

64. Sarti, Servo e padrone; idem, "The Servant's Freedom". 
avoid”. He was on slippery ground: recognizing the servants' limited freedom meant supporting exclusion; underlining their free will meant crediting them as people who, by choosing subjection, were unworthy of citizenship. $\mathrm{He}$ resorted to a subtle argument - need - urging the Assembly to intervene in a revolutionary way in its causes, presented as a "disorder": "Your wisdom, gentlemen, will put an end to this kind of disorder". The response of the president of the Assembly was patronizing. ${ }^{65}$

On the same day, a decree dissolved all military corps except the National Guard, excluding "passive" citizens (and thus also domestics) from military service. ${ }^{66}$ For servants, the outcome of the first year of the Revolution was disappointing. Far from being removed, their dependence and lack of freedom and equality were seen as reasons to exclude them from citizenship. Attacks on the aristocracy and economic crisis had boosted unemployment. Servants had protested and made proposals, unsuccessfully. Only the abolition of liveries supported their dignity (19 June I790). ${ }^{67}$ Other measures implied a "negative" emancipation: "clerks or administrators, people who had been subject to feudal power, secretaries, carters or farm managers employed by owners, tenants, or sharecroppers" should not be considered domestiques and not be excluded from active citizenship if they had the other requisites (20 March 1790). ${ }^{68}$ On I2 August 1790, "librarians, tutors, craftsmen who have completed their apprenticeship, shop assistants, and bookkeepers" were also declared not to be domestics. ${ }^{69}$ While some domestiques presented themselves as a corps ("body"), ${ }^{70}$ these measures showed how blurred the notion of domestique was. $^{7 \mathrm{I}}$

The Constitution, approved on 3 September 179I, reserved suffrage to "active" citizens, i.e. people born or naturalized French, aged at least twenty-five, domiciled in the city or canton by the time established by law, who paid taxes valued at three working days, who were enrolled in the municipal National Guard, and who were not domestics. ${ }^{72}$ The active/passive citizens distinction was abolished when the insurrection of 10 August 1792

65. Adresse des gens de maison à l'Assemblée Nationale... (Paris, [1790]); AP-XVI, p. 20I; Sarti, Servo e padrone, pp. I I 4-I I8.

66. Florence Devenne, "La Garde Nationale: création et évolution (I789-août I792)", AHRF, 283 (1990), pp. 49-66, 55; Georges Carrot, La Garde Nationale (1789-I87I). Une force publique ambiguë (Paris, 200I), p. I I 5 .

67. AP-XVI, pp. $375-378$.

68. $A P-\mathrm{XII}, \mathrm{pp} .260-262$.

69. $A P-X V I I I$, p. 4 I.

70. See note 58.

7I. Raffaella Sarti, “Le 'nom de domestique' est un 'mot vague'. Débats parlementaires sur la domesticité pendant la Révolution française”, Mélanges de l'École française de Rome. Italie et Méditerranée modernes et contemporaines, I3 I:I (2019), pp. 39-52. Available at: https://journals.openedition.org/mefrim/5937; last accessed 28 May $202 \mathrm{I}$.

72. Constitution, 3 September I79I, tit. III, ch. I, sect. II, art. 2. 
(which also involved servants) ${ }^{73}$ caused the Legislative Assembly to suspend the king and to hold elections for the Convention, charged with preparing another constitution. Yet, the domestiques were not enfranchised. ${ }^{74}$ Their exclusion was also explicit in the decree on elections in the colonies, where, notwithstanding some male white servants, domestic staff were mainly female and/or freed slaves, often creole. ${ }^{75}$ Being a domestique was increasingly demeaning. ${ }^{76}$ Some people who felt unjustly considered as such protested, ${ }^{77}$ and the authorities clarified that only those employed in personal services were excluded, not those working in industry, trade, or agriculture. ${ }^{78}$

Others who considered themselves domestiques claimed citizenship. On 28 August I792, a deputation of domestiques was allowed to address the Assembly. ${ }^{79}$ Why were servants excluded ${ }^{80}$ The view that only citizens with property loved their fatherland was typical of aristocratic systems, and not founded on men's rights. In France and America, loving freedom and equality sufficed for one to be considered a patriot. The sophisms used to exclude the domestiques could also apply to a millionaire's factory workers. Servants were craftsmen living with their employers. Their love of their fatherland and freedom came before their love of their masters. They were sans-culottes enragés; all sans-culottes were brothers, and all patriots active citizens. "Nature, our common mother, makes us servants of one another. A man is worth a man." ${ }^{8 \mathrm{I}}$ Signed by twenty-seven people, the petition had been written not by a servant, but by revolutionary baron Anacharsis Cloots. ${ }^{82} \mathrm{~A}$ few days later, a certain Mr Picho asked in the "name of all citizens in a state of domestic servitude" that "the equality of men be complete and that the large class of service people be allowed to enjoy all the inalienable and inviolable rights of man like all the other members of society". ${ }^{83}$

These requests went unheeded. Yet, things were changing. On is February I793, Condorcet, on behalf of the comité de Constitution, argued that dependence preventing free choices was a legitimate reason for exclusion, but such

73. George Rudé, The Crowd in the French Revolution (London, [1959 $\left.{ }^{\mathrm{I}}\right]$, 1967), p. 106.

74. AP-XLVIII, pp. 29, 430.

75. AP-XLVIII, p. 621, art. 7; Gautier, Sours, Kindle pos. 3944ff; Moitt, Women, p. 59; Florence Gauthier, L'aristocratie de l'épiderme. Le combat de la Société des Citoyens de Couleur, I789-I79I (Paris, 2007), Kindle pos. 277.

76. AP-XLVIII, p. 3 I9.

77. AP-XLIX, p. 25 .

78. Ibid., p. 35 .

79. Ibid., p. 73 .

80. $A P-\mathrm{L}, \mathrm{pp} .67 \mathrm{I}-672$.

8. Ibid.

82. Roland Mortier, Anacharsis Cloots ou l'utopie foudroyée (Paris, 1995); François Labbé, Anacharsis Cloots, le Prussien francophile (Paris and Montreal, 1999); Alexander Bevilacqua, "Conceiving the Republic of Mankind: The Political Thought of Anacharsis Cloots", History of European Ideas, 38:4 (2012), pp. 550-569.

83. AP-XLIX, p. 463. 
dependence would not exist "under a truly free Constitution, and in a people where the love of equality is the distinctive feature of public spirit. The social relationships that would presume such humiliation cannot exist between us". Equality should be "used to remove what remain[ed] of this dependence", instead of enshrining dependence in the laws. ${ }^{84}$ In winter-spring 1793 , many proposals advocated the enfranchisement of servants. ${ }^{85}$ According to Saint-Just's, "the law does not recognize masters among citizens; it does not recognize domestic servitude. It recognizes an equal and sacred commitment of care between the man who works and the one who pays him". ${ }^{86}$ According to this revolutionary perspective, servants and masters were men with equal dignity linked by an economic exchange. Furthermore, on Io June I793 the law on commons partition established that the partition be made per head for all inhabitants, including domestiques. ${ }^{87}$

On 24 June, after the Jacobins defeated the Girondins, the new Constitution was approved. It did not exclude servants. Article i 8 stated: "Every man can pledge his services and his time; but he cannot sell himself or be sold; his person is not alienable property. The law does not recognize domestic servitude; only a bond of care and gratitude can exist between the man who works and the one who employs him." ${ }^{88}$ It forbade slavery and unveiled a revolutionary view of domestic work. The requisites to enjoy citizenship were inclusive. ${ }^{89}$ Yet, their final version, unlike the first, required people to be "domiciled" in France - i.e. to own or rent the house where they lived - to prevent rich men from hiring domestics to vote for them, a requirement that excluded servants who lived with their masters. ${ }^{90}$ Thus, the 1793 Constitution enfranchised servants, but restricted their access to vote..$^{91}$ It was never applied. ${ }^{92}$ The 1795 Constitution reintroduced the suspension of political rights for domestiques à gages. ${ }^{93}$ Such suspension, only formally abolished in I806 in cantonal assemblies, ${ }^{94}$ was confirmed in $1837 .{ }^{95}$ Male servants would be enfranchised when universal male suffrage was introduced (5 March I848).

84. AP-LVIII, pp. $583-596$.

85. Sarti, Servo e padrone, pp. I38-144.

86. $A P-X L I I I$, pp. 200-2 I 5 .

87. AP-LXVI, pp. $225-226$ (section II, art. 4). The implementation of the law was soon blocked:

Sarti, Servo e padrone, pp. I $50-15$ I.

88. AP-LVII, pp. I43-I45, Déclaration des droits de l'homme et du citoyen, p. I44, art. I8.

89. De l'état des citoyens, art. 4.

90. AP-LXVI, p. 283.

91. Verjus, "Vote familialiste", p. 3 I, note 6.

92. AP-LXXVI, p. 3 I 2.

93. Titre II, État politique des citoyens, art. I 3.

94. Rosanvallon, Le sacre; Décret Impérial No. I 255, I 7 January i 806, Bulletin des lois, 4.e série, vol. IV (Paris, I 806), pp. 216-237.

95. Mittre, Des domestiques, p. I7; Louis Rondonneau, Collection des lois françaises constitutionnelles, vol. I (Paris, I8 I I), p. 3. 
Yet, they could not be elected to municipal councils until $1930,{ }^{96}$ nor be jurés until 1932. ${ }^{97}$ Article 178 I of the 1804 Civil Code (repealed in I 868 ) also violated equality: in cases of disagreement over wages, without written evidence the master's statement under oath would be accepted, ignoring the servant's. ${ }^{98}$

Notwithstanding the Déclaration des droits, during the Revolution the domestiques never really enjoyed full citizenship. The freedom and equality principles aroused new suspicions: seeing them as people who choose not to be free, many considered them unworthy of citizenship. Nonetheless, new ideas emerged. To state in a constitution (although never applied) that the law did not recognize domestic servitude showed a glimpse of a world without masters nor servants.

\section{EQUALITY AND FREEDOM FOR BLACK SLAVES, TOO?}

In Bordeaux, on 25 August 1789 , a crowd of servants gathered demanding a doubling of salaries, a placement office, the right not to wear liveries, and that "the coloured servants who harmed white domestics" be dismissed and sent back. The cavalry dispersed them. Some were punished. ${ }^{99}$ In this port city, crucial for the connection with the colonies, black people were numerous. What was the impact of the Revolution on slavery? The question is relevant when dealing with the regulation of domestic service because some domestics in France and many in the colonies were slaves. Furthermore, the revolutionary emphasis on freedom created new commonalities between service and slavery. ${ }^{100}$

In eighteenth-century France, opposition to slavery and the slave trade gained momentum. Condorcet argued for gradual abolition, to prevent disorder. ${ }^{\text {IOI }}$ Olympe de Gouges maintained that "human beings are everywhere equal”, denouncing the slave trade. ${ }^{102}$ The Société des Amis des Noirs was

96. Olivier Fourcade, De la condition civile des domestiques (Paris, I 898), pp. I 52-1 53; Loi du 8 janvier 1930 supprimant le quatrième alinéa de l'article 32 de la loi du 5 avril I 884 sur l'organisation municipale. Available at: https://www.legifrance.gouv.fr/jorf/id/JORFTEXTo000003 I 2970; last accessed I 3 June $202 \mathrm{I}$.

97. Decree 7 August I 848 . See Fourcade, De la condition, pp. I $50-15$ I; Loi du 13 février 1932 conférant aux domestiques et gens de maison le droit d'être juré. Available at: https://www.legifrance.gouv.fr/jorf/id/JORFTEXT0000003 I3222; last accessed I 3 June 202 I.

98. M.D. Dalloz and M. Armand Dalloz, Répertoire méthodique et alphabétique de législation ... nouvelle édition, vol. 30 (Paris, I853), pp. 548-549; André Castaldo, "L’histoire juridique de l'article 178 I du Code civil. 'Le maitre est cru sur son affirmation'”, Revue historique de droit français et étranger, 55:2 (1977), pp. 2 I I-237; Gutton, Domestiques, p. I34.

99. Michel Lhéritier, Les débuts de la Révolution à Bordeaux... (Paris, I919), pp. 88-89.

ı०o. Fairchilds, Domestic Enemies, p. I 8.

ıоI. M. Schwartz [=Condorcet], Réflexions sur l'esclavage des nègres (Neuchâtel, I78I).

I02. Olympe de Gouges, "Réflexions sur les hommes nègres", in idem, Zamore et Mirza, ou L'beureux naufrage... (Paris, 1788), pp. 92-99, 93; the piece was republished with more explicit 
founded (I 9 February I788). ${ }^{103}$ In spring 1789 , its president, Condorcet, sponsored the creation of a commission to abolish the slave trade and slavery, ${ }^{104}$ and contended that the colonies' deputies, representing only white people, should be excluded from the Estates General. ${ }^{105}$ On their very opening day (5 May 1789), the Minister of Finance Necker denounced the huge share of the royal trade subsidies enjoyed by the slave trade; it could be halved. ${ }^{106}$ On 27 June, de la Rochefoucauld asked the deputies to address black people's freedom. ${ }^{107}$ Abolitionist texts were being published. ${ }^{108}$ The Amis des Noirs planned a motion on slave trade abolition (the first step towards slavery abolition). ${ }^{109}$ Yet, money and products linked to the slave trade and slavery were fundamental for the French economy. ${ }^{10}$ The supporters of colonial interests would defend slavery strenuously. In summer I 789 , some of them founded the influential Club de l'Hôtel de Massiac. ${ }^{\text {III }}$

claims of slaves' liberty, as L'esclavage des noirs ou L'beureux nanfrage (Paris, 1792). Gisela Thiele-Knobloch, "Olympe de Gouges (1748-1793). "Eine Todfeindin der Sklaverei'”, Feministische Studien, 2 (I99I), pp. I40-I44; Gregory S. Brown, "Abolitionism and Self-Fashioning: Olympe de Gouges and her Esclavage des Noirs, I783-1792”, Proceedings of the Western Society for French History, 27 (1999), pp. 2 I0-2 I 9; Catherine Masson, "Olympe de Gouges, anti-esclavagiste et non-violente", Women in French Studies, io (2002), pp. I53-165; Anaïs Cécile Pédron, "Olympe de Gouges, anti-esclavagiste et anticolonialiste?", in Pascale Pellerin (ed.), Les Lumières, l'esclavage et l'idéologie coloniale. XVIII -XX siècles (Paris, 2020), pp. I55-I79.

103. La Révolution française et l'abolition de l'esclavage. Textes et documents, I 2 vols (Paris, 1968) [hereafter, RFAE], vol. 6; Daniel P. Resnick, "The Société des Amis des Noirs and the Abolition of Slavery", French Historical Studies, 7:4 (1972), pp. 558-569; Françoise Thésée, "Autour de la Société des Amis des Noirs. Clarkson, Mirabeau et l'abolition de la traite (août 1789-mars 1790)", Présence africaine, I25 (1983), pp. 3-82; Lawrence C. Jennings, "The Interaction of French and British Antislavery, 1789-1848", Proceedings of the Meeting of the French Colonial Historical Society, is (1992), pp. 8I-9I; Koufinkana, "Les esclaves"; Marcel Dorigny and Bernard Gainot, La Société des Amis des Noirs 1788-I799. Contribution à l'histoire de l'abolition de l'esclavage (Paris, I998); Jean-Pierre Barlier, La Société des Amis des Noirs, I788I79I. Aux origines de la première abolition de l'esclavage (4 février I794) (Paris, 2010).

I04. Condorcet, Lettre à MM. les Députés des Trois Ordres, pour les engager à faire nommer [...] une Commission chargée d'examiner la cause des Noirs ([Paris], [May I789]), in RFAE, vol. 7, no. I, pp. I-5I.

I05. Condorcet, Sur l'admission des députés des planteurs de Saint-Domingue ..., in RFAE, vol. 6, no. 8, pp. I 57-166; Jacques Binoche, "Les députés d’Outre-Mer pendant la Révolution Française (1789-1799)”, $A H R F$, 50:23 I (1978), pp. 45-80.

I06. Thésée, "Autour de la Société des Amis des Noirs", p. 7.

107. AP-VIII, p. I65.

108. See RFAE.

I09. Thésée, "Autour de la Société des Amis des Noirs", p. 8.

I Io. Dubois, "Histoires d'esclavage", p. 75.

I I I. Lucien Leclerc, "La politique et l'influence du Club de l'Hôtel Massiac", $A H R F$, I 4:82 (1937), pp. 342-363; Jean Tarrade, "Les colonies et les principes de 1789. Les assemblées révolutionnaires face au problème de l'esclavage", Outre-Mers. Revue d'histoire, 76:282 (1989), pp. 9-34; David Geggus, "Racial Equality, Slavery, and Colonial Secession during the Constituent Assembly”, The American Historical Review, 94:5 (1989), pp. I 290-I 308; Déborah 
Meanwhile, in Martinique a slave rebellion started, prompted by the false news that the king had abolished slavery. The Declaration of Rights was still unknown in the colony, unlike Condorcet's plans to put slave trade abolition on the National Assembly's agenda. The rebels had more radical views. "We know that we are free", they wrote in a letter signed "we, the Blacks" (Nègres), accusing the colony's authorities of not enforcing the alleged abolition. "Well, remember that we nègres are numerous, and we want to die for this liberty." Slave owners did not free them. The uprising started. Rebels were dispersed and punished. ${ }^{\text {II }}$ In Saint-Domingue, too, several slaves believed they were free; others asked for three days a week free from plantation work. Slave gatherings were taking place, and one slave tried to kill his master, arguing that "now we are all equal by order of the King". ${ }^{I_{3}}$

The supporters of slavery emphasized this unrest in their virulent campaign, arguing that abolition would be disastrous for France (abolitionists presented it as beneficial). ${ }^{\text {I }}{ }^{4}$ Olympe de Gouges's antislavery piece was cancelled after three performances following violent attacks. ${ }^{\text {II }}$ Amid these tensions, the Amis des Noirs submitted their address advocating abolition of the slave trade, ${ }^{116}$ but Mirabeau was not even allowed to deliver his speech. ${ }^{17}$ The National Assembly decreed that the laws approved for the kingdom did not apply to the colonies. It would not intervene in any area of commerce (alluding to the slave trade) and guaranteed the colonists' properties (including slaves). The principles of the Déclaration des droits sounded like empty words. ${ }^{\mathrm{I} 8}$ Slavery was untouched. Slave trade subsidies continued. ${ }^{119}$ There were still slaves even in France, although their status was increasingly unclear. ${ }^{120}$

Liébart, "Un groupe de pression contre-révolutionnaire. Le Club Massiac sous la Constituante", AHRF, 354 (2008), pp. 29-50; Régent et al., Les colonies.

I I 2. Laurent Dubois, “'Citoyens et amis!' Esclavage, citoyenneté et République dans les Antilles françaises à l'époque révolutionnaire”, Annales. Histoire, Sciences Sociales, 58:2 (2003), pp. 279303, 290; idem, A Colony of Citizens: Revolution and Slave Emancipation in the French Caribbean, $1787-1804$ (Chapel Hill, NC, and London, 2004), pp. 86-87; idem and John D. Garrigus, Slave Revolution in the Caribbean, $1789-1804$ (London, 2006).

II3. John D. Garrigus, Before Haiti: Race and Citizenship in French Saint-Domingue (New York, 2006), p. 230.

I I4. AP-X, p. 258 , Adresse [...] qui suppliait l'Assemblée nationale de rejeter toute motion quitendrait à l'abolition de la traite; Thésée, "Autour de la Société des Amis des Noirs", pp. 44-45; Gauthier, Aristocratie, ch. I.

i I5. De Gouges, L'esclavage, p. 2; Olivier Blanc, Olympe de Gouges: Une femme des libertés (Paris, 1989), pp. 68-79; Thésée, "Autour de la Société des Amis des Noirs", p. 63.

I 16. AP-XI, pp. 273-277, Adresse de la Société des Noirs de Paris, pour l'abolition de la traite des Noirs (2 I January 1790).

I 17. Thésée, “Autour de la Société des Amis des Noirs”, pp. 63, 66-68.

I I 8. $A P$-XII, pp. 68-73, 72 .

I 19. They were cancelled in September I793. See Jean Vidalenc, "La traite des nègres en France au début de la Révolution (1789-1793)”, $A H R F$, 29:146 (1957), pp. 56-69, 69.

I 20. Boulle, "Élaboration", p. 37. 
Some continued petitioning the Admiralty Court for their freedom. ${ }^{\text {I2I }}$ On I 2 October 1790, the National Assembly decreed that it would not change people's status in the colonies without a request from the colonial assemblies: this meant retaining slavery and the discrimination of free blacks and people of mixed descent (gens de couleur). ${ }^{\mathrm{I} 22}$

The latter, whose status had worsened over time, suffered from innumerable discriminations. ${ }^{\mathrm{I} 3}$ Those who lived in France were children of wealthy colonial families sent there to be educated or trained, former slaves who had become free domestiques, and people born in France to mixed parents. ${ }^{\mathrm{I} 4} \mathrm{In}$ March 1789, some gens de couleur from Saint-Domingue asked to be represented at the Estates General; in August, the Société des citoyens de couleur was formed. Its members campaigned to enjoy the Rights of Man and to elect their deputies. ${ }^{\mathrm{I2} 5}$ They did not question slavery but asked that children of free men and female slaves be free and their mothers be freed; they requested the right to go and stay in France, and full restoration of the free-soil principle. ${ }^{\mathrm{I} 26}$ They pursued a new colonial order: white and coloured slave owners should foster the gradual improvement in conditions among slaves. ${ }^{127}$ White colonists resisted these requests. From I790, clashes unsettled SaintDomingue. ${ }^{128}$ The National Assembly meanwhile approved ambiguous and contradictory decrees. However, on 28 September I79I, the free-soil principle was restored and skin colour was declared irrelevant - in France as regards citizenship. ${ }^{\text {I29 }}$

Colonial slaves who could not set foot on French soil were making their way towards freedom. "Here, Sirs, a new order of things begins", deputy Tarbé

I 2 . Peabody, "There are No Slaves in France", p. I38. The court was dismissed in November 1790.

I22. $A P-\mathrm{XIX}, \mathrm{p} .570$.

I 23. Julien Raimond, Observations sur l'origine et les progrès du Préjugé [...] contre les Hommes de couleur (Paris, 176I); idem, Réclamations adressées à l'Assemblée nationale par les personnes de couleur... (n.p., n.d.); John Garrigus, "Redrawing the Colour Line: Gender and the Social Construction of Race in Pre-Revolutionary Haiti", Journal of Caribbean History, 30:1 82 (1996), pp. 29-50; Gauthier, Aristocratie, Kindle pos. 4946ff; Carminella Biondi, "Le problème des gens de couleur aux colonies et en France dans la seconde moitié du XVIIIe siècle", Crombos, 8 (2003), pp. I-I2; Érick Noël, "Les libres de couleur dans le jeu politique en France en 1789 . Origines, implications, devenir”, in Régent et al., Les colonies, pp. 4I- 52.

I 24. Noël, "Les libres".

I 25. Gauthier, Aristocratie, passim.

126. Cabier Contenant les Plaintes, Doléances E Réclamations des Citoyens-Libres E Propriétaires de Couleur... (n.p., I789).

I 27. Gauthier, Aristocratie, Kindle pos. 804 .

I 28. Ibid., passim; John D. Garrigus, “'Thy Coming Fame, Ogé! Is Sure’: New Evidence on Ogé’s I 790 Revolt and the Beginnings of the Haitian Revolution”, in John D. Garrigus and Christopher Charles Morris (eds), Assumed Identities: The Meanings of Race in the Atlantic World (Arlington, VA, 2010), pp. 19-45.

I29. $A P-\mathrm{XXXI}, \mathrm{pp} .44^{2-443}$. 
wrote in a report on Saint-Domingue. "The uprising of the blacks breaks out." ${ }^{\circ}{ }^{\circ}$ While the first slave actions had taken place in January I79I after the gens de couleur uprising led by Vincent Ogé and Jean-Baptiste Chavannes, ${ }^{131}$ the insurrection began on 22-23 August 179I. ${ }^{132}$ A network of African, creole, black, and mixed-descent slaves (both domestic and plantation ones, often commandeurs), maroons, and some free people of colour had prepared the revolt, probably launched with a voodoo ceremony. ${ }^{\mathrm{I3} 3}$ A slave culture was developing, intermingling African elements and European revolutionary values: an executed insurgent had "pamphlets printed in France [claiming] the Rights of Man" in his pocket; "on his chest he had a little sack full of hair, herbs, bits of bone, which they call a fetish". ${ }^{134}$ The insurrection spread. Anything that had to do with slavery was destroyed and white people were killed. ${ }^{135}$

On 28 March I792, the Assemblée Législative eventually decreed equality between whites, free black, and mixed-descent people in the colonies. Some deputies pursued racial equality, others searched for allies to restore slavery in Saint-Domingue. ${ }^{136}$ There, the civil commissioners sent by the Assemblée - Sonthonax and Polverel - tried unsuccessfully to unite whites and free men of colour. ${ }^{\mathrm{I} 7}$ In May 1793, the new Governor, Galbaud, arrived and allied with pro-slavery colonists against the commissioners. Meanwhile, the British attacked the French West Indies to prevent the slave rebellion from spreading to Jamaica and to stop the Spanish invasion of Saint-Domingue supported by slave rebels (spring-summer I793). ${ }^{138}$ On 2 I June, Sonthonax and Polverel granted freedom and the rights of French citizenship "to the black warriors" who would fight with them. ${ }^{139}$ Many blacks joined them. At the end of June, Galbaud and several thousand colonists fled to the US. On 24 August, in Le Cap, I 5,000 people voted in favour of emancipation. ${ }^{140}$ Sonthonax decreed the end of slavery in the north of SaintDomingue (29 August 1793), as did Polverel shortly afterwards in the south

I30. $A P-\mathrm{XXXV}$, pp. 700-710, 706.

I3I. Carolyn E. Fick, The Making of Haiti: The Saint Domingue Revolution from Below (Knoxville, TN, I990), pp. 267-269; Garrigus, Before Haiti, pp. 25 I-252.

I32. Garrigus, Before Haiti, pp. 260-263.

133. Fick, Making of Haiti, pp. 91-95, 104-105.

134. Ibid., p. I I .

135. Ibid., pp. 95-97.

I36. $A P-\mathrm{XL}$, pp. $575-578,577$.

I37. Amadou Mahtar M’Bow, "L'insurrection des esclaves de Saint-Domingue. Le bicentenaire de Haït”, Présence Africaine, I69 (2004), pp. I I-32; Garrigus, Before Haiti, p. 268.

I38. Thomas O. Ott, The Haitian Revolution, I789-I804 (Knoxville, TN, I973), pp. 76-78; Laurent Dubois, Avengers of the New World (Cambridge, MA, 2004), pp. I I7-I I 8.

I39. Régent, "Préjugé", p. i7.

I40. Dubois, Avengers, pp. I 54-163. 
and west. On 3 I October 1793 slavery was completely abolished. ${ }^{\mathrm{I}}{ }^{\mathrm{I}}$ The principle that "Men are born and live free and equal in rights" was law in the colony. This is "France's Gospel", Sonthonax declared. ${ }^{\text {I2 }}$

Abolition was not gradual, as had been planned by the Amis des Noirs, but sudden, due to the plantation owners defending their privileges, the slave uprising, the Spanish and British invasions, the commissioners' need for soldiers. The Revolution turned the armed defence of the nation into a crucial feature of citizenship. This was even more so for slaves: fighting for the revolutionary republic proved an avenue to freedom and, for males, to enfranchisement, too. Elections took place in Saint-Domingue on 23 September 1793. Newly freed slaves may have voted. ${ }^{\mathrm{I} 3}$ There was a perfected "pigmentational" balance among the elected: three blacks, three whites, and three of mixed blood. Jean-Baptiste Belley - a symbol of black emancipation thanks to his portrait by Girodet-Trioson $(1798)^{\mathrm{I} 44}$ - was one of the three sent to Paris. ${ }^{145}$ Through the sudden abolition of slavery and the enfranchisement of male slaves, the colony had strained the principles of freedom and equality to a point unforeseen in the metropole, possibly transforming the "compass of universalism itself". ${ }^{46}$

However, things were changing in France, too. On Is May I793, the coloured soldiers' legion created in September 1792 was dissolved: the soldiers refused to go to the colonies, fearing they would be enslaved. ${ }^{\mathrm{I} 47}$ Some of them demanded the abolition of slavery. The metropole and the colonies were part of the same nation, but black slaves were excluded from the prerogatives granted by the Revolution. "Why, then, this difference, in rights, between equal men?" ${ }^{48}$ On 3 June (the day after the Girondins' arrest), the Jacobins received a delegation of blacks, promising slave liberation; then the

I4I. Fick, Making of Haiti, ch. 7; Dubois, “'Citoyens”, p. 293; Garrigus, Before Haiti, p. 298; Dubois, Avengers, pp. 163-166.

I42. Proclamation, 29 August I793. Available at, for instance, https://mjp.univ-perp.fr/constit/ htI 793. htm; last accessed I 3 June $202 \mathrm{I}$.

I43. According to Gauthier slaves voted, according to Dubois this was possible but there is no proof. Florence Gauthier, "The Role of the Saint-Domingue Deputation in the Abolition of Slavery”, in Marcel Dorigny (ed.), The Abolitions of Slavery from Léger Félicité Sonthonax to Victor Schoelcher, I793, I794, I848 (Paris, 2003), pp. 167-179, 171; Dubois, A Colony of Citizens, pp. I59-160.

I44. Musée de l'Histoire de France, Versailles; Jean-Louis Donnadieu, "Derrière le portrait, l'homme. Jean-Baptiste Belley, dit 'Timbaze', dit 'Mars' (1746?-1805)”, Bulletin de la Société d'Histoire de la Guadeloupe, I70 (2015), pp. 29-54. Before Belley, another black deputy had been admitted, Janvier Littée, from Martinique. See Binoche, "Les députés d'Outre-Mer”, p. 69. I 45. Gauthier, "The Role of the Saint-Domingue Deputation”, p. i7 I. For safety reason, some deputies and substitutes stayed behind.

I46. Dubois, A Colony of Citizens, p. I68.

I47. Gauthier, “The Role of the Saint-Domingue Deputation”, p. I68.

148. Adresse [...] pour les Nègres détenus en esclavage dans les colonies françaises... (Paris, 27 May

I793), p. 9. 
Convention and the Commune of Paris also received them. ${ }^{\mathrm{I} 9}$ The new Constitution, approved on 24 June, banned slavery: "Every man can pledge his services and his time; but he cannot sell himself or be sold; his person is not alienable property" (article I 8). Yet, the Constitution's enforcement was postponed. Slavery was abolished when the Saint-Domingue's deputies took their seats (3 February 1794). By confirming their election, the Convention implicitly confirmed the abolition of slavery in Saint-Domingue. ${ }^{\mathrm{I}}{ }^{\circ}$ The day after, abolition was extended to all French colonies. ${ }^{\text {III }}$ The decree contemplated neither a transitional phase between slavery and freedom nor compensation for slave owners. This meant freedom was regarded as more important than property rights, delegitimizing slavery completely. Initially, measures to enforce abolition were taken. A decree allowed pro-slavery activists to be arrested (9 March 1794). ${ }^{152}$ After months of conflict against the colonists and the English, a general freedom was proclaimed in Guadeloupe (I I December 1794). Abolition was (partially) enforced also in Guyana, but not in Martinique, under English occupation, nor in the Indian Ocean colonies: the English controlled the maritime routes and the colonists opposed it. ${ }^{153}$

The I793-I794 general freedom was ambiguous: many rebel slaves had already freed themselves; freed slaves were paid but were required to work for their former masters without having the freedom to quit. ${ }^{154}$ However, when the Convention abolished slavery, the slave revolt leader François-Dominique Toussaint Louverture, until then allied with Spain, joined the republican French army. He was appointed colonel and then general - the first black general - and French Governor's Lieutenant. The war with Spain ended in 1795. An armistice with Britain was signed in 1798. Louverture developed an independent policy, even proclaimed a constitution that, although recognizing that Saint-Domingue was French, made him life-long governor with the right to appoint his successor (I 80I). ${ }^{155}$ To get the support of the plantation owners and stimulate the economy, he prevented plantation labourers from leaving without permission and made their status immutable (I2 October I 800). This provoked new uprisings. In I802,

I49. Gauthier, "The Role of the Saint-Domingue Deputation”, pp. I69-170.

I 50. Ibid., pp. I71-172.

I 5 I. "Décret N. 2262 de la Convention Nationale [...] qui abolit l'Esclavage des Nègres dans les Colonies", in $R F A E$, vol. I 2 , no pagination.

I 52. Gauthier, "The Role of the Saint-Domingue Deputation", p. I73.

I 53. Dorigny, Les abolitions de l'esclavage, pp. 58-59; Dubois, A Colony of Citizens, p. I 53.

I 54. Régent, "Préjugé”, pp. I9-2 I; idem, La France et ses esclaves, pp. 3 I0-3 I 7; Fick, Making of Haiti, pp. I67-168; Judith Kafka, "Action, Reaction and Interaction: Slave Women in Resistance in the South of Saint Domingue, I793-94”, Slavery E Abolition, I 8:2 (1997), pp. 48-72; Dubois, Avengers, pp. 195-196; Dorigny, Les abolitions de l'esclavage, pp. 102-103.

I 55. Available at: http://thelouvertureproject.org/index.php?title=Haitian_Constitution_of_i 80 I_ (French); last accessed 29 May $202 \mathrm{I}$. 
Napoleon sent an army to Saint-Domingue to restore French authority; Louverture was arrested and sent to France, where he died in $1803 .{ }^{156}$

On 20 May I 802, France established that slavery would be maintained where it had never been abolished. This was the case with Martinique, occupied by the British and returned to France in I802, but not with Saint-Domingue and Guadeloupe. Yet, on I6 July i 802, Napoleon reintroduced slavery in Guadeloupe. Shortly before, black and coloured people were prevented from entering metropolitan France without authorization (2 July I 802), while in the colonies the gens de couleur in I 802-1 80 5 were disenfranchised (until I 833). Consequently, the leaders of the Saint-Domingue army continued the war against the French and won. Independence was proclaimed on I January I 804: Saint-Domingue became Haiti. The Constitution declared all Haitians "black" and prevented white people (except for naturalized ones) from owning property (I805). ${ }^{157}$ There were complex links between the Haitian and French revolutions. In France, the phase during which there had been concrete efforts to enforce the Declaration of Rights was over. But by existing, it had marked an important discontinuity.

\section{A GENDERED PERSPECTIVE}

Besides campaigning for black equality, Olympe de Gouges supported women's rights. Her Declaration of the Rights of Woman and Female Citizen (I79I) advocated the full inclusion of women among citizens, showing the inconsistency between the universalism of revolutionary principles and the exclusion of women, half of humankind. ${ }^{\text {is }}{ }^{8}$ She was one of the first female

I 56. Fick, Making of Haiti, pp. 207-208; Dubois, Avengers, p. 238.

I 57. Dubois, Avengers, p. 300; Régent, "Préjugé", pp. 23-25; Constitution, 20 May I805, Déclaration préliminaire, articles I2, I4. Available at: https://mjp.univ-perp.fr/constit/hti 805 . htm; last accessed 29 May $202 \mathrm{I}$.

I 5. Olympe de Gouges, Déclaration des droits de la femme et de la citoyenne (Paris, I791). Available in English at: https://www.olympedegouges.eu/rights_of_women.php; last accessed 29 May 202 I. Blanc, Olympe; Joan Wallach Scott, Only Paradoxes to Offer: French Feminists and the Rights of Man (Cambridge, MA, 1996), pp. 19-56; Hannelore Schröder, "The Declaration of Human and Civil Rights for Women (Paris, I79I) by Olympe de Gouges", History of European Ideas, I I (1989), pp. 263-27I; Marie Josephine Diamond, "Olympe de Gouges and the French Revolution: The Construction of Gender as Critique”, Dialectical Anthropology, I5:2/3 (1990), pp. 95-105; Marie Josephine Diamond, "The Revolutionary Rhetoric of Olympe de Gouges", Gender Issues, I4 (1994), pp. 3-23; Ute Gerhard, "Sulla libertà, uguaglianza e dignità delle donne. Il 'differente' diritto di Olympe de Gouges”, in Gabriella Bonacchi and Angela Groppi (eds), Il dilemma della cittadinanza. Diritti e doveri delle donne (Rome-Bari, I993), pp. 37-58; Jürgen Siess, "Un discours politique au féminin. Le projet d'Olympe de Gouges”, Mots. Les langages du politique, 78 (2005), pp. 9-2 I; Sophie Mousset, Women's Rights and the French Revolution: A Biography of Olympe de Gouges (New Brunswick, 2007); John R. Cole, Between the Queen and the Cabby: Olympe De Gouges's Rights of Woman (Montreal, 20II); Carol L. Sherman, Reading Olympe de Gouges 
activists who, in Europe and America, fought both against slavery and for women's rights, although not without a degree of racist prejudice. ${ }^{159}$ She stressed commonalities in the circumstances of being female and being a slave, ${ }^{160}$ yet, anticipating intersectionality, ${ }^{16 \mathrm{I}}$ she also highlighted the consequences of intermingling gender and race oppressions. In the Ancien Régime there was a kind of trade in women, she explained. Women bought by men, like African female slaves, could improve their circumstances only through seduction and corruption, but there was an important difference: a female slave, although perhaps able to command her master through seduction, might be freed with no recompense when her charm was lost. What would then become of the unfortunate woman $?^{162}$ De Gouges also denounced the particularly inhumane implications of illegitimacy in the colonies, where the children of colonists and slave women (often domestics) were frequently their father's slaves. ${ }^{163}$

Under the 1685 Code Noir, if a free man had children with a slave, he and the slave's master were required to pay a fine; if the father was the slave's master, and was married, the slave and child would be confiscated. If he was unmarried, he was required to marry the slave, freeing her and the children, and legitimizing the latter (article 9). ${ }^{164}$ This provision was disregarded. Interracial marriages were discouraged. Interracial sexual libertinage, however, remained common. ${ }^{165}$ Sexual intercourse with masters might bring about manumission (manumitted slaves were mainly women and children). ${ }^{166}$ But harassment and rape were embedded in the condition of female slaves, abused by their masters

(New York, 2013); Martine Reid, "Femme, réveille-toi!". Déclaration des droits de la femme et de la citoyenne et autres écrits (Paris, 2014); Joshua Rivas, "The Radical Novelty of Olympe de Gouges", Nottingham French Studies, 53:3 (2014), pp. 345-358.

I 59. Anna Rossi-Doria, La libertà delle donne. Voci della tradizione politica suffragista (Turin, 1990); Doris Y. Kadish and Françoise Massardier-Kenney (eds), Translating Slavery: Gender and Race in French Women's Writing, $1783-1823$ (Kent, OH, 1994); Ana Stevenson, "The Abolitionists of Slavery among Women': Transatlantic Foundations of the Woman-Slave Analogy", in Marcus K. Harmes et al. (eds), The British World: Religion, Memory, Society, Culture (Toowoomba, 2012), pp. 1 59-169.

I60. Olympe de Gouges, Le bonheur primitif de l'homme, ou Les rêveries patriotiques ([Paris], I789), p. I04.

16r. Kimberle Crenshaw, "Mapping the Margins: Intersectionality, Identity Politics, and Violence against Women of Color”, Stanford Law Review, 43:6 (I99I), pp. I 24I-I 299.

162. De Gouges, Déclaration, p. I5.

163. Ibid., pp. 20-2 I.

164. Sala-Molins, Le Code Noir.

165. Gautier, Sours, Kindle pos. 3722; Doris L. Garraway, The Libertine Colony: Creolization in the Early French Caribbean (Durham, NC, 2005); Arlette Gautier, "Genre et esclavage aux Antilles françaises. Bilan de l'historiographie”, in Philippe Hroděj (ed.), L'esclave et les plantations (Rennes, 2009), pp. I6I-I 84; Cécile Vidal, "Femmes et genre dans les historiographies sur les sociétés avec esclavage (Caraibes anglaise et française, XvIIe-mi-XIXe siècle)", Clio. Femmes, Genre, Histoire, 50 (2019), pp. I89-2 10.

166. Gautier, Sours, Kindle pos. $3554 \mathrm{ff}$; Moitt, Women, p. I 5 I. 
and other men of any ethnicity, free and unfree. ${ }^{167}$ Their offspring were slaves of their mothers' owners (article I 2). Nonetheless, and despite measures to increase population growth, the birth rate among slaves in the French Caribbean (as in most other colonies of the region) was below the reproduction rate. ${ }^{168}$ Their harsh living conditions negatively affected pregnancies and the survival of their babies: women were employed in the most arduous of plantation tasks; only a few were domestiques, who received better food, clothing, and accommodation and were more often manumitted, although they were always on call and more exposed to their masters' sexual assaults. ${ }^{169}$ Yet, abortion and infanticide might imply a refusal to reproduce slaves, and was therefore severely punished. ${ }^{170}$

The "domestic" and patriarchal organization of the plantations, significantly called habitations, exacerbated the oppression of female slaves. The babitation was a place of work and life, including fields, pastures, woods, the establishments to process and stock products, the slave huts with their gardens, the infirmary, the kitchens, and the house of the master (grande case). Although the colonists often did not reside on the plantations, the habitation's life was organized around the grande case, which symbolized a master's power. ${ }^{171}$

Female slaves resisted slavery in ways other than abortion and infanticide, from poisoning to marronage. ${ }^{172}$ Many took part in the uprising. Although some, especially domestics, remained loyal to their masters, ${ }^{173}$ slaves at the top of slave hierarchy, such as domestics, played a crucial role in organizing the insurrection. ${ }^{174} \mathrm{~A}$ voodoo priest and a priestess, an elderly African woman, likely officiated at the ceremony that probably started the I79I uprising in Saint-Domingue ${ }^{175}$ (voodoo gave central roles to women). Women like former mixed-race domestique Solitude in Guadeloupe or slaves like Sanité Bélair and Marie-Jeanne Lamartinière in Saint-Domingue - served in

167. Gautier, Sceurs, Kindle pos. 33 I 3ff; Moitt, Women, pp. 99-100.

168. Gautier, Sceurs, Kindle pos. 2097; Fick, Making of Haiti, p. 27; Moitt, Women, pp. I5, 89 (an exception was Barbados); Dubois, A Colony of Citizens, pp. 68-69.

I69. Gautier, Sours, ch. 7; Moitt, Women, chs 3 and 4.

170. Gautier, Soeurs, Kindle pos. 2826; Moitt, Women, ch. 7; Garraway, The Libertine, Kindle pos.

222.

I7I. Natacha Bonnet, "La plantation coloniale: champs de cannes à sucre et esclavage à Saint-Domingue au xviIIe siècle", in Guy Saupin and Jean-Luc Sarrazin (eds), Économie et société dans la France de l'Ouest Atlantique. Du Moyen Âge aux Temps modernes (Rennes, 2004), pp. 28 I-298; Natacha Bonnet, "L'organisation du travail servile sur la sucrerie domingoise au XVIIIle siècle”, in Hrodèj (ed.), L'esclave, pp. I 25 -1 59.

172. Bernard Moitt, "Slave Women and Resistance in the French Caribbean", in David Barry Gaspar and Darlene Clark Hine (eds), More Than Chattel: Black Women and Slavery in the Americas (Bloomington, IN, 1996), Kindle pos. 6178ff.

173. Gautier, Sceurs, Kindle pos. 4197.

174. Ibid., Kindle pos. 5074 .

175. Ibid., Kindle pos. $5039 \mathrm{ff}$; Fick, Making of Haiti, p. 93. 
the army, collaborated as spies and messengers, transported ammunition and food, cared for the wounded, prostituted themselves in exchange for bullets, and encouraged men with songs and slogans. ${ }^{176}$

The outcome was disappointing. The 1794 Convention decree abolished slavery for men and women, but stressed "the passage from slavery to manhood": "the male slave-turned-soldier" was crucial in shaping emancipation in the French Caribbean. ${ }^{177}$ Paid forced labour introduced to "save" the plantation system ${ }^{178}$ implied lower wages for women, despite female protests. ${ }^{179} \mathrm{In}$ independent Haiti, men took on new political, professional, and military roles; women were assigned almost only those of food producers and mothers (fertility rates increased). Although important in commerce, they were mainly employed on plantations and in domestic work. This division of labour was rooted in slave plantations, which reserved skilled occupations to men. Yet, it was more gendered. Already Toussaint Louverture's Constitution (I $80 \mathrm{I}$ ) aimed to build a new, patriarchal, plantation system. ${ }^{80}$ After independence, the nation was represented as a family led by patriarchal leaders. ${ }^{18 \mathrm{I}}$ Universal active male suffrage was introduced in $18 \mathrm{I} 6$, women were excluded until 1950. ${ }^{182}$ In pre-revolutionary Saint-Domingue and in the French colonies, where slavery was never abolished or reintroduced, most black women suffered from intermingling oppressions due to gender, race, and slavery. In post-independence Haiti, where slavery was banned and all citizens were assumed to be black, ${ }^{183}$ women faced exclusions due to gender: a more gendered society was established. Similarly, in the French West Indies, after

I76. Kafka, "Action, Reaction and Interaction"; Philippe Girard, "Rebelles with a Cause: Women in the Haitian War of Independence, I 802-04”, Gender E History, 2 I: I (2009), pp. 60-85; Laurent Dubois, "Gendered Freedom: Citoyennes and War in the Revolutionary French Caribbean", in Karen Hagemann, Gisela Mettele, and Jane Rendall (eds), Gender, War and Politics: Transatlantic Perspectives, $1775-1830$ (New York, 2010), pp. 58-70.

177. Dubois, $A$ Colony of Citizens, p. I62.

178. Fick, Making of Haiti, pp. 207-208; Dubois, Avengers; Dubois, “'Citoyens”, pp. 297-298. 179. Gautier, Sours, Kindle pos. 5142; Fick, Making of Haiti, p. I70; Kafka, "Action, Reaction and Interaction", pp. 48-49, 54; Dubois, "Gendered Freedom", p. 66.

I 80. Available at: https://thelouvertureproject.org/index.php?title=Haitian_Constitution_of_i 80I_ (English); last accessed 29 May $202 \mathrm{I}$.

I8 I. Constitution, 20 May I805, Déclaration préliminaire; Gautier, Sœurs, Kindle pos. 5 I $42 \mathrm{ff}$; Dubois, "Gendered Freedom", pp. 59, 66-68.

I82. Laurent Dubois, Haiti: The Aftershocks of History (New York, 20I 2), pp. 60-6I; Grace Sanders, "Women and the Vote". Available at: http://islandluminous.fiu.edu/parto9-slide22. html; last accessed 29 May 202 I; Grace Louise Sanders, "La voix des femmes: Haitian Women's Rights, National Politics, and Black Activism in Port-Au-Prince and Montreal, 1934-1986" (Ph.D., University of Michigan, 2013). Available at: https://deepblue.lib.umich.edu/handle/ 2027.42/99799; last accessed 29 May $202 \mathrm{I}$.

I 83. Constitution, 20 May i 805 , Déclaration préliminaire, articles 2, I 4. Available at: https://mjp. univ-perp.fr/constit/hti 805 . htm; last accessed I 3 June 202 I. 
the 1848 emancipation of slaves the main dichotomy was no longer slave/free but male/female. ${ }^{184}$

Besides differences, there were commonalities with metropolitan France. There, too, women took part in the Revolution in many forms, from insurrection to publication of feminist texts. ${ }^{185}$ Although some domestiques, especially chambermaids employed by the elites, remained loyal to their counterrevolutionary masters, among revolutionary women there were servants dismissed for being patriots and maids employed by revolutionaries. Some revolutionary servants are known, such as cook Constance Evrard, a member of the Republican Revolutionary Women and friend of Pauline Léon's. ${ }^{86}$ There were also women among the servants who supported the Revolution and campaigned for their rights as domestiques. ${ }^{187}$ On I 2 June 1790 , when the domestiques addressed the National Assembly, they delivered a patriotic offer: probably the first to suggest that male and female domestics offer six livres to the nation was a maid (whose name was not recorded). Furthermore, the domestiques who (unsuccessfully) tried to create an institution to assist unemployed and aged domestiques and servants' orphans included women. ${ }^{188}$

For female domestiques the Revolution's outcome was even more disadvantageous than for males. Although called citoyennes, ${ }^{189}$ they suffered from exclusions not only as domestiques but also, more drastically, as women. The Revolution's results were disappointing for all women. A fictional dialogue summarized the expectations of many women: a chambermaid calls

I84. Myriam Cottias, "Gender and Republican Citizenship in the French West Indies, I8481945", Slavery \& Abolition, 26:2 (2005), pp. 233-245.

I85. Paule-Marie Duhet, Les Femmes et la Révolution 1789-I794 (Paris, I971); Louis Devance, "Le féminisme pendant la Révolution française", $A H R F, 229$ (1977), pp. 34I-376; Joan B. Landes, Women and the Public Sphere in the Age of the French Revolution (Ithaca, NY, 1988); Carole Pateman, The Sexual Contract (Stanford, CA, 1988); Geneviève Fraisse, Muse de la raison. La démocratie exclusive et la différence des sexes (Aix-en-Provence, 1989); Olwen Hufton, Women and the Limits of Citizenship in the French Revolution (Toronto, 1992); Dominique Godineau, "Femmes en citoyenneté. Pratiques et politique", AHRF, 300 (I995), pp. 197-207; Scott, Only Paradoxes; Anne Verjus, Le cens de la famille. Les femmes et le vote, I789-I 848 (Paris, 2002); Dominique Godineau, Citoyennes tricoteuses. Les femmes du peuple à Paris pendant la Révolution française (Paris, 2004), transl. The Women of Paris and their French Revolution (Berkeley, CA, 1998); Anne Verjus, La citoyenneté politique au prisme du genre. Droits et représentation des individus entre famille et classe de sexe (XVIIIe-XXIe siècles) (Paris, 20I4); Guillaume Mazeau and Clyde Plumauzille, "Penser avec le genre. Trouble dans la citoyenneté révolutionnaire”, La Révolution française, 9 (2015), pp. I-27; Suzanne Desan, "Recent Historiography on the French Revolution and Gender", Journal of Social History, 52:3 (2019), pp. 566-574.

186. Godineau, The Women of Paris, pp. 55-56, 106, 109, 2 16, 255 ; Rudé, The Crowd, p. I 5 I, I 83 , I97, 2 I 2, 230; Révolutions de Paris, No. 81, 22-29 January 1791, p. I 37.

I87. Sarti, Servo e padrone, pp. i 16-I 24.

I 88. Révolutions de Paris, No. XII, 4 October 1786 [1789], p. 42; Sarti, Servo e padrone, pp. I I6I 17.

I89. Dominique Godineau, “Autour du mot citoyenne”, Mots, I6 (I988), pp. 9I-I I0, I08. 
her mistress "citizen" rather than "your ladyship". "I am a republican and nothing else, you pay me and I serve you, and we are equal", she explains to the lady. ${ }^{190}$ Achieving equality between maid and mistress, both enjoying citizenship, and replacing personal dependency with a contractual exchange of services for wages would have been revolutionary. In fact, equality between mistress and maid meant both remaining disenfranchised for another century and a half, or even being banned more radically than earlier, as was the case with those women who, being taxpaying widows or single, had been eligible to elect the Estates General, or those who voted on the partition of the commons. ${ }^{191}$ Between late 1792 and the first half of 1793 , women's enfranchisement seemed possible. Yet, for many male revolutionaries, citizenship implied independence. Thus, male domestics and women of any class, being socially constructed as dependent, were excluded. Female exclusion, however, was more radical: male domestics could change their occupation; for a while, during the Revolution, at least on paper, they were considered citizens; they were enfranchised in I $848 .{ }^{192}$ In autumn 1793 , French women were declared not fit for policy, "destined by nature" to the domestic sphere and prevented from political participation. ${ }^{193}$ Olympe de Gouges, who was guillotined on 3 November 1793, may be considered a symbol of the repression of female claims. ${ }^{194}$ French women would not become full citizens until as late as $2 \mathrm{I}$ April $1944 \cdot{ }^{195}$

After the Revolution, dependency became more closely associated with women: there was a feminization of dependency. ${ }^{196}$ Domestic staff feminization contributed to this change. By the first decade of the twentieth century, women made up about ninety per cent of the number of domestic personnel

I90. "Dialogo tra la cameriera democratica e la padrona aristocratica", La Sferza repubblicana, I 4 August 1798, and Giornale de' Patrioti d'Italia, in Renzo De Felice (ed.), I giornali giacobini italiani (Milan, I962), pp. 47I-472.

I9I. René Larivière, "Les femmes dans les assemblées de paroisses pour les élections aux États généraux de 1789", Bulletin d'histoire économique et sociale de la Révolution française (1974), pp. I 23-1 56; Serge Aberdam, "Deux occasions de participation féminine en I793. Le vote sur la Constitution et le partage des biens communaux", AHRF, 339 (2005), pp. I7-34.

192. Sarti, Servo e padrone, p. I60.

193. For a summary in English, see "Discussion of Women's Political Clubs and Their Suppression, 29-30 October 1793", in World History Commons. Available at: https://worldhistorycommons.org/discussion-women $\% \mathrm{E}_{2} \% 80 \% 99$ s-political-clubs-and-their-suppression- $29 \% \mathrm{E}_{2}$ $\% 80 \% 9330$-october-1793; last accessed 29 May 202 I.

194. Fenille du salut public, 3 November 1793: "it seems that the law has punished this conspirator for forgetting the virtues that suit her sex".

195. Ordonnance du 2 I avril I944. Available at: http://www2.assemblee-nationale.fr/decouvrir-lassemblee/histoire/le-suffrage-universel/la-conquete-de-la-citoyennete-politique-des-femmes/ladecision-du-general-de-gaulle; last accessed 29 May $202 \mathrm{I}$.

196. Sarti, Servo e padrone, pp. 2 1 8-222. On the US, see Nancy Fraser and Linda Gordon, "A Genealogy of Dependency: Tracing a Keyword of the US Welfare State”, Signs, 19:2 (1994), pp. 309-336. 
employed in France. ${ }^{197}$ The feminization of domestics was also symbolic: until the first few decades of the twentieth century, manservants were forbidden to grow a moustache. ${ }^{198}$ The Revolution emphasized the domestic role of women, feeding the "separate spheres" ideology that associated women with the private and men with the public. Such ideology influenced many people's behaviour, but the social organization was more complex. ${ }^{199}$ However, the servant feminization made the houses of servant-keeping families more feminized, contributing to the domestic sphere's feminization. Women servants - performing tasks ever more considered "naturally" feminine and done for free, out of "love", by wives and mothers - experienced increasing difficulty in being considered proper workers. At a time when workers' rights, in general, were receiving greater recognition, those employed in domestic work began to be disqualified as "workers". It was felt that activities related to the daily routine of the home were not proper "work"; there was a "delabourization" under way in this sector. ${ }^{200}$ Women of different classes, considered dependent, were excluded from full citizenship and bound to allegedly natural roles within increasingly feminized domestic spaces: gender became more important as a marker of differences not only in the colonies but also in metropolitan France.

However, the domestic sphere remained legally headed by the husband/ father/master. The Revolution had democratized family relations a little thanks to civil marriage and divorce (20 September 1792), inheritance equality among siblings (March 1793), and the assimilation of legitimate and recognized illegitimate children (I 2 brumaire I793). Yet, divorce was repealed in I 8 I 6 (until I 884); the Napoleonic Civil Code (I 804) reintroduced a sharp distinction between legitimate/illegitimate children, even preventing paternity investigations (article 340), and emphasized the authority of the male head of the family. Despite many conflicts and contradictions, the public sphere

197. Raffaella Sarti, "Notes on the Feminization of Domestic Service: Bologna as a Case Study (I8th-19th Centuries)", in Antoinette Fauve-Chamoux and Ludmila Fialová (eds), Le phénomène de la domesticité en Europe, XVIe-XXe siècles (Prague, 1997), pp. I25-163; idem, "Domestic Service: Past and Present in Southern and Northern Europe", Gender E History, I 8:2 (2006), pp. 222-245, 228, Table 2.

198. Idem, "Fighting for Masculinity: Male Domestic Workers, Gender, and Migration in Italy from the Late Nineteenth Century to the Present", Men and Masculinities, I 3 (2010), pp. I6-43. 199. Leonore Davidoff and Catherine Hall, Family Fortunes: Men and Women of the English Middle Class, 1789-1850 (London, I987); Amanda Vickery, "Golden Age to Separate Spheres? A Review of the Categories and Chronology of English Women's History”, Historical Journal, 36:2 (1993), pp. 383-4I4; Leonore Davidoff, "Gender and the 'Great Divide': Public and Private in British Gender History”, Journal of Women's History, i s:I (2003), pp. I I-27; Raffaella Sarti, Europe at Home: Family and Material Culture I500-I800 (New Haven, CT, and London, 2002), pp. 236-238; Sarti, Servo e padrone, pp. 21 2-2 I 8.

200. Sarti, Servo e padrone, pp. 203-2 I 2; Idem, Anna Bellavitis, and Manuela Martini (eds), What is Work? Gender at the Crossroads of Home, Family, and Business from the Early Modern Era to the Present (New York, 2018), pp. I 5-22. 
moved towards a growing democracy; the domestic one continued to be marked by hierarchical relationships crucial in establishing who enjoyed full citizenship, the citizen largely overlapping with the family head. ${ }^{201}$ In the colonies, the domestic sphere, in a sense, covered the whole slave production system, being the plantations (babitations) organized as households headed by the master/slave owner. Besides many differences, there were intricate similarities between the metropolitan domestic sphere and the colonies.

\section{BEYOND THE FRENCH IMPERIAL NATION STATE: A FEW COMPARATIVE SUGGESTIONS}

This article has explored the "French imperial nation-State". Comparisons with other cases - the American for instance - would obviously be interesting. Before concluding, let me thus suggest a few observations to stimulate comparative reasoning. While revolutionary France eventually included universal freedom in a constitution, in the US this was not the case. In 1776 , the Declaration of Independence held as "self-evident" "truths" that "all men are created equal" and that "they are endowed by their Creator with certain unalienable Rights, that among these are Life, Liberty and the pursuit of Happiness". ${ }^{202}$ Yet, the US Constitution abolished neither slavery ${ }^{203}$ nor indentured service. ${ }^{204}$

Regulating suffrage was crucial to the French constitutions, whereas the American one "neither limited nor broadened the suffrage anywhere, since it left the issue to the individual states". ${ }^{205}$ Free African-Americans had been enfranchised in some states during the American Revolution, but from I 790 they were disenfranchised. This process took place while the socioeconomic barriers to voting (property, tax-paying) disappeared for whites, opening up political participation to a growing proportion of the white male population, including adult male free domestic servants. ${ }^{206}$

20I. Marcel Garaud and Romuald Szramkiewicz, La Révolution française et la famille (Paris, 1978); Irène Thery and Christian Biet, La Famille, la Loi, l'Etat. De la Révolution au Code Civil (Paris, 1989); Xavier Martin, "Fonction paternelle et Code Napoléon", AHRF, 305 (1996), pp. 465-475; Jennifer Heuer and Anne Verjus, "L'invention de la sphère domestique au sortir de la Révolution”, AHRF, 327 (2002), pp. I-28; Sarti, Servo e padrone, pp. 195-225.

202. Available at: https://www.archives.gov/founding-docs/declaration-transcript; last accessed 29 May $202 \mathrm{I}$.

203. John P. Kaminski (ed.), A Necessary Evil? Slavery and the Debate over the Constitution (Madison, WI, 1995).

204. Howard Zinn, A People's History of the United States: 1492-Present (New York, [1980] 2015), p. 84 .

205. Donald Ratcliffe, "The Right to Vote and the Rise of Democracy, I787-1 828", Journal of the Early Republic, 33:2 (2013), pp. 219-254, 23 I.

206. Ibid., pp. 246-247; David Montgomery, Citizen Worker: The Experience of Workers in the United States with Democracy and the Free Market during the Nineteenth Century (New York, 1993), p. I4. 
While in France the Revolution had implied several interventions to clarify and limit the people covered by the term domestique, until the mid-nineteenth century the word "servant" was rarely used in the US when referring to white native domestic servants, generally called "help". ${ }^{207}$ Such white servants appeared arrogant to European travellers, although performing even the humblest duties. ${ }^{208}$ As noted by Tocqueville (I $835-1840$ ), in the northern states there were numerous whites "willing, in return for wages, to submit temporarily to the will of people like themselves", without perceiving themselves inferior to the person who gave them orders. They supported Tocqueville's ideas on "how democracy modifies relations between servant and master". Yet, in the South, slavery continued to exist, and, in the North, many servants were freed slaves or their children, with ambiguous and contested status. ${ }^{209}$ Race was a major barrier preventing the democratization of the master-servant relationship.

Like Olympe de Gouges, who fought for the rights of both black people and women, American feminists had strong links with abolitionism. ${ }^{20}$ Like the French Revolution, the American one produced a clearer-cut legal exclusion of women from institutional political participation, although stimulating other forms of public intervention, often inspired by the ideas of "Republican motherhood". ${ }^{\text {II }}$ After the American Revolution, in fact, "most states specifically disenfranchised women, even when property holders". ${ }^{212}$ Despite this similarity, gender, race, and dependency intermingled differently in France and the US.

\section{CONCLUSION}

The impact of the French Revolution was complex. Serfs were freed. Slaves experienced liberty, at least for a while. The "general freedom" did not foresee any transitional phase or compensation for slave owners, which implied seeing freedom as an indispensable human right and delegitimizing slavery

207. Lucy M. Salmon, Domestic Service (New York, [1897] 1901), pp. 70-72; Faye E. Dudden. Serving Women: Household Service in Nineteenth-Century America (Middletown, MA, 1983), pp. 2-3, 44, 60; Sarti, "The Globalisation of Domestic Service”, p. 80. The word "servants" would be reintroduced to address white servants when they became dominated by immigrants, especially Irish.

208. Grégoire, De la domesticité, pp. 60-72; Sarti, Servo e padrone, pp. $225-229$.

209. Alexis de Tocqueville, Democracy in America, trans. Arthur Goldhammer, ed. Oliver Zunz (New York, 2004), pp. 675-676, 669.

2 I0. See note I 59; Karen Sánchez-Eppler, Touching Liberty: Abolition, Feminism, and the Politics of the Body (Berkeley, CA, I993).

2 I I. Linda K. Kerber, Women of the Republic: Intellect and Ideology in Revolutionary America (Williamsburg, VA, I980), p. 36.

2 I 2. Ratcliffe, “The Right to Vote”, p. 229. 
completely. Male former slaves were enfranchised. Yet, colonial slaves had freed themselves through uprisings. Slavery continued in the French Indian Ocean colonies and in Martinique, occupied by the British. ${ }^{213}$ Where abolition was enforced, it was replaced by bonded labour (similar to serfdom). ${ }^{214}$ Slavery was restored some years after abolition. Former Saint-Domingue slaves managed to become independent and created a black nation. The abolition of slavery in the French colonies would finally be decreed in $\mathrm{I} 848$. As in the I 790 s, thereafter former slaves experienced bonded labour. In I 848 universal male suffrage was introduced and male domestics were enfranchised. Before that date, metropolitan "free" domestic servants had never really enjoyed citizen rights, although on paper, for a short period (I793-I795), male ones had not been excluded. Even after i 848, however, they suffered from discrimination until the 1930s. ${ }^{215}$ The Declaration of Rights represented an important discontinuity but led to a permanent change in legal status only for serfs and, through tortuous paths, Haitian slaves. However, the slaves of Guadeloupe and Guyana, both men and women, experienced freedom at least for a while, whereas metropolitan "free" domestiques had their status changed only if they were men, exclusively on paper, and for a short period.

The third revolutionary principle, fraternité is crucial to understanding how the other two were interpreted by most revolutionaries: freedom and equality among brothers. ${ }^{216}$ Gender was crucial. For women, the Revolution's outcome was even more disappointing than for slaves and male domestiques. Despite their revolutionary engagement, they were never recognized as full citizens and were eventually declared unfit for political life. They would be enfranchised (2 I April 1944) almost a century after the final abolition of slavery and the enfranchisement of male domestics. Domestic servants, already largely female at the end of the Ancien Régime, in the following decades experienced a process of feminization, contributing to the feminization of dependency. Race, dependence on a master, and gender turned out to be strong barriers to freedom and equality. ${ }^{217}$ After the abolition of slavery, gender became more important than race in determining individual rights in the French colonies, too, and this was also the case in the former colony of Saint-Domingue, the black nation of Haiti, where universal male suffrage was introduced in 1816 , female in 1950 .

While women of every status and colour suffered from long-lasting discrimination, the colonies experienced slavery and then bonded labour, whereas the metropolitan labour market slowly witnessed, despite tensions and conflicts, a

2 13. Dorigny, Les abolitions de l'esclavage, pp. 58-59.

214. Régent, "Préjugé", p. 25.

2 I 5 . Dorigny, Les abolitions de l'esclavage, pp. 103-104; Stanziani, "Beyond Colonialism”; Sarti, Servo e padrone, p. 160.

216. Pateman, The Sexual Contract.

217. Sarti, Servo e padrone, pp. 195-22 I; Dubois, A Colony of Citizens, p. 7. 
democratization and recognition of workers' rights. This was not the case with paid and unpaid domestic and care work, which experienced "delabourization". ${ }^{218}$ The colonies as a whole and the metropolitan households were places where freedom and equality encountered barriers: an outcome that in part questions the metropole/colonies divide.

The Declaration of Rights was a promise only partially kept. Nonetheless, its universalism provided people - including slaves, servants, blacks, and women - with powerful arguments to support their claims, and also encouraged new ways of considering differences: a long-lasting legacy. 